\title{
Chemistry Wastewater Treatment of El-Oued City (South-east of Algeria) by Utilization of Typha Latifolia
}

\section{ZEGHDI SAAD, BEBBA AHMED ABDELHAFID and LAOUINI SALAH EDDINE}

Laboratory of Recovery and Promotion of Saharan Resources, University of Kasdi Merbah, 30000 Ouargla, Algeria.

${ }^{*}$ Corresponding author E-mail: salah_laouini@yahoo.fr

http://dx.doi.org/10.13005/ojc/320625

(Received: September 05, 2016; Accepted: November 10, 2016)

\begin{abstract}
The objective of this study is to show the potential of Typha latifolia in the Purification performance of wastewater in the region of El Oued (southeast of Algeria). The pilot scale consists of two beds of plastics, filled with gravel and sand. One was planted saplings Typha latifolia at 36 stems $/ \mathrm{m}^{2}$, the second was not planted serves as a control (witness). The results show good yields for suspended solids and organic pollution, removal rates are $96,76 \%$ for (SS) $89,92 \%$ for the Chemical Oxygen Demand (COD) and $87,98 \%$ for biochemical oxygen demand in 5 days $\left(\mathrm{BOD}_{5}\right)$. There is a clear increase in the concentration of dissolved oxygen (DO). The system effectively removes nitrite $(88.84 \%)$, nitrate $(91.20 \%)$, and orthophosphate $(93.12 \%)$.
\end{abstract}

Keywords: Typha latifolia, Wastewater, Treatment; Phytopurification; Arid climate.

\section{INTRODUCTION}

The purification of wastewater by use of plants is a technique for the treatment that has been experiencing since soon a thirty year a wide success of by the world. This technique of treatment is especially known to be ecological and economic. The épuratoires performance of this kind of system are very satisfactory, the treated wastewater by the plants are large of the same quality as those that come out of a good classical system equipped with unit of denitrification and phosphate removal ${ }^{1}$. It has been used in different countries belonging to different regions and under different climates: in Australia ${ }^{2}$, Burkina ${ }^{3-4}$, Cameroon $^{5}$, Italy ${ }^{6}$, China ${ }^{7}$. In Jordan ${ }^{8}$, Morocco $^{9-10-11}$, Niger $^{12}$. In Côte d'Ivoire ${ }^{13}$, Mexico ${ }^{14-15}$, in Europe ${ }^{16}$. It is used for the purification of different types of wastewater Domestic ${ }^{4-17-18}$, wastewater from the olive industry ${ }^{19}$. waters of rain ${ }^{20}$, wastewater of tannery ${ }^{21}$, wastewater of slaughterhouse ${ }^{22}$. Effluent of hog barns ${ }^{23}$, wastewater in agriculture ${ }^{24}$, wastewater containing heavy metals ${ }^{25}$, wastewater of dairy farms ${ }^{26}$. In addition, effluents from Medical Laboratories ${ }^{27}$, The technique has been tested with success for the organic pollution ${ }^{28}$ for the elimination of phosphates ${ }^{29}$, of the nitrogen and metals ${ }^{29-30}$, and 
the elimination of pathogenic germs. It has also been used for the stabilization of sewage sludge, for the purification of air and it has even been proposed for space applications ${ }^{31}$. The first pilot unit using the scrubber power plants in Algeria was carried out in the region of Témacine (wilaya of Ouargla) ${ }^{32}$. This pilot experience has identified certain constraints in the more important is the unsuitability of certain plants to the arid climate, on a total of 21 species that have been planted 18 species have perished, where the importance of the choice of the purifying plants which must be done in a way thorough.

In our work it is to test the performance purifying of plant which is resistant to the climatic conditions of an arid climate, namely the Typha latifolia in order to know to what extent this last could it be used in the treatment of wastewater.

\section{MATERIALS AND METHODS}

\section{Presentation of the study area}

The city of El Oued situated to the South East of Algeria, in the northern reaches of the Erg Oriental $\left(33^{\circ}\right.$ to $34^{\circ}$ north and $6^{\circ}$ to $8^{\circ}$ is). It is characterized by an arid climate. The average annual temperature is of the order $22,66^{\circ} \mathrm{C}$, the warmest month is July with $34.43^{\circ} \mathrm{C}$, the coldest month is January with $10.76^{\circ} \mathrm{C}$. The warm period lasts from May to October, with an average of $29.98^{\circ} \mathrm{C}$. This period knows a significant evaporation which can achieve the $33.44 \mathrm{~mm}$ in the month of July. The peak of insolation corresponds to the month of June, with an hourly volume of 344 hours. The annual average of the insolation is 273,40 hours/month. The cold period, spreads from November to April, with an average of $14,99^{\circ} \mathrm{C}$. The rainfed period of the year is very short ( 2 to 3 months), the annual precipitation averages are of the order of $5.47 \mathrm{~mm}$. The moisture average annual is of the order of $47,39 \%$. The values of the Moisture oscillate between $67.7 \%$ during the month of December, $30.9 \%$ during the month of July ${ }^{33}$. The region is also characterized in spring and summer by winds dry and hot causing the sirocco or "Chihili" appear during the summer period and sand storms.

\section{Choice of the plant}

In the literature the purifying different have been used: the Pistia stratiotes ${ }^{25}$, water hyacinth ${ }^{10}$, Imperata cylindrica ${ }^{34}$, Phragmites australis, 35-36-37-38-39-40, Typha latifolia ${ }^{41-36-39-40-11,}$ Scipus validus, Juncus effusus, Typhadomin gensis, Amaranthus, Chorcourus, Nerium oleander, Tamarix Africa, papyrus cypurus ${ }^{39}$, Arundo Donax, Tilapia and Panicum maximum ${ }^{13}$. Taylor et $a^{R 8}$ has tested 19 different plants for the elimination of the organic load. Carex aquatilis Wahlenb, Carex bebbii Olney, Carex microptera Mack., Carex nebrascensis, Carex praegracilis, Carex utriculata, Schoenoplectus acutus, Calamagrostis canadensis, Deschampsia cespitosa (L.), Hordeum jubatum L., Leymus cinereus, Panicum virgatum L., Phalaris arundinacea L, Phragmites australis (Cav.), Juncus arcticus, Juncus torreyi, Typha latifolia L. , Iris issouriensis, Prunella vulgaris $L$. has Témacine 21 species have been planted at the beginning of the experience: Ficus carica, Vetiver zizanioides, Laurus nobilis, Jasminum grandiflora, Lantana camara, Touggourt pink, Damascus Rose, Hibiscus rosa sinensis, Nerium oleander, Mentha spicata, Cyperus spp., Ionicera caprifolium, Pelargonium Rosa, Punica granatum, Morus nigra, Atriplex halumis, Typha latifolia, Washingtonia spp., Cymbopogon citratus, Juncus spp., Canna edulis, 18 species on the 21 planted at the beginning of the experience have not resisted to the conditions of the local climate.

The present study focused on a plant Typha latifolia also called reed to hammer, rauche, or cattail. This plant is adapted to local climatic conditions and which is resistant to very difficult conditions. It is a plant of the family of Typhaceae, it is the most common of the genus Typha. Its flowering period runs from July to September and its vegetative rest has place in winter. Its growth is rapid, it can measure between 1.5 and $3 \mathrm{~m}$ high. This plant develops a root system important which stabilizes the substrates and provides nests for the development and the supply of microorganismes.

\section{Presentation of the experimental protocol}

The experimental driver consists of two drums of plastics of a capacity of 130 liters, filled from the bottom to the top on a thickness of $45 \mathrm{~cm}$ of gravel and $10 \mathrm{~cm}$ of sand (Figure 1). A too-full is placed $5 \mathrm{~cm}$ below the sand to avoid any overflow of water. The keg is planted with young stems to reason to $36 \mathrm{stems} / \mathrm{m}^{2}$. The drums are powered by with semi trailers of water of 30 the once a week. The 
waters come from the wastewater having undergone a treatment Primary treatment at the level of the sewage plant in Kouinine (north of the city of ElOued).

The flow is done in percolation through the substrate. The residence time of the water is of 5 days. The treated waters are recovered by a tap placed in the bottom of the WAS.

Water samples are collected after primary treatment at the level of the water treatment station located at Kouinine (north exit of the city). The analyzes were carried out at the Laboratory of recovery and promotion of Saharan resources of

Table 1: Physico-chemical characteristics of the effluent to treat

\begin{tabular}{lc}
\hline Parameters & The Levels \\
\hline $\mathrm{PH}$ & 7.87 \\
$\mathrm{EC}(\mathrm{mS} / \mathrm{cm})$ & 6.05 \\
$\mathrm{SS}(\mathrm{mg} / \mathrm{L})$ & 330,19 \\
$\mathrm{DCO}(\mathrm{mg} / \mathrm{L})$ & 326,07 \\
$\mathrm{DBO}$ & $(\mathrm{mg} / \mathrm{L})$ \\
$\mathrm{Dissolved} \mathrm{Oxygen}(\mathrm{mg} / \mathrm{L})$ & 166.58 \\
$\mathrm{NO}_{2}^{-}(\mathrm{mg} / \mathrm{L})$ & 0.72 \\
$\mathrm{NO}_{3}^{-}(\mathrm{mg} / \mathrm{L})$ & 0.27 \\
$\mathrm{PO}_{4}{ }^{3-}(\mathrm{mg} / \mathrm{L})$ & 17.01 \\
\hline
\end{tabular}

the University of Ouargla and the Laboratory of the sewage treatment plant at Kouinine. Our measures have worn on nine parameters: $\mathrm{pH}$, electrical conductivity, SS, COD, BOD5, dissolved oxygen, nitrite, nitrate and orthophosphate.

For the determination of the $\mathrm{pH}$, we used a $\mathrm{pH}$ meter Hanna ( $\mathrm{pH} 213)$. The conductivity has been determined with the help of a multi-parameter ( $\mathrm{HQ}$ Hach40d). For the SS and according to the quantity of suspended solids, two methods have been used: method of filtration on fiberglass according to the Standard (NF EN 872:1996) and the centrifugation according to the standard (NF T 90-105-2). The dissolved oxygen is determined by an oximeter (WTW pH/Oxi $340 \mathrm{i}$ ), the $\mathrm{BOD}_{5}$ was determined by a

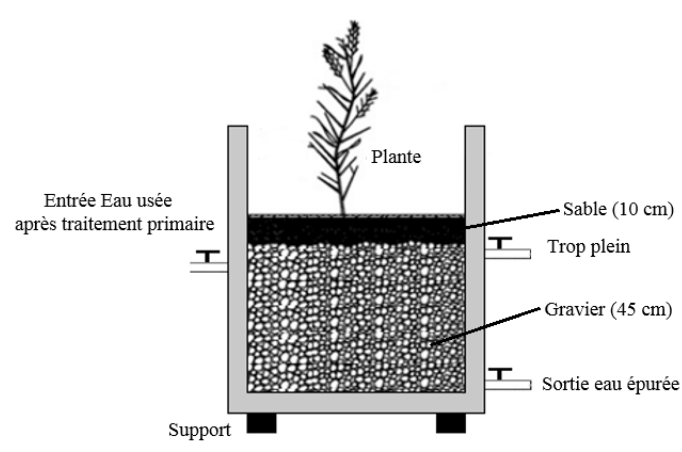

Fig. 1: Experimental device

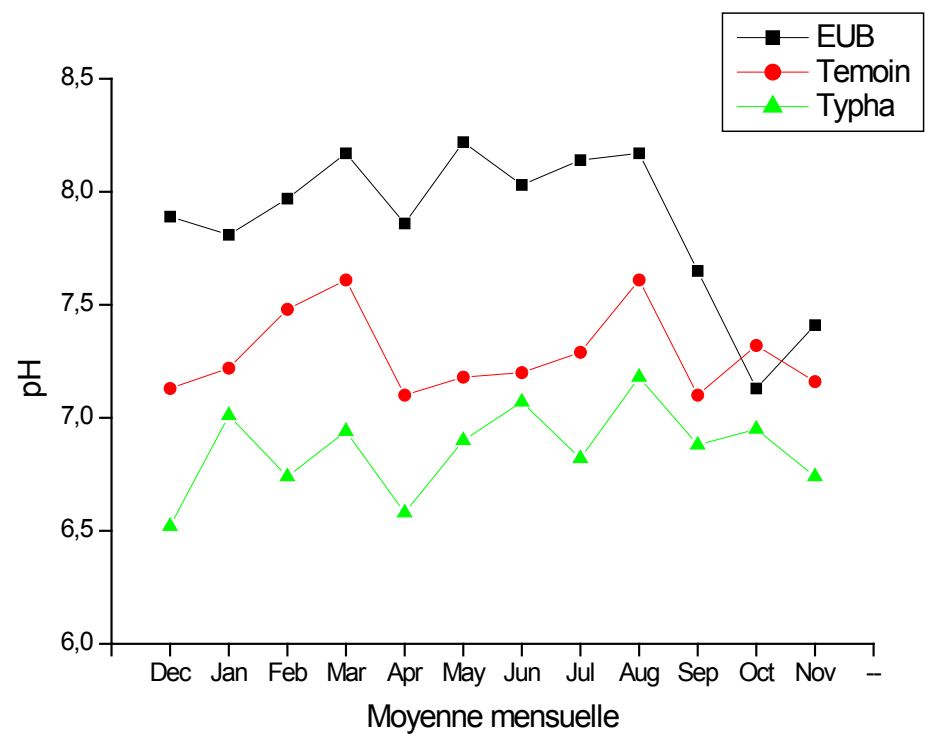

Fig. 2: Temporal Evolution of the $\mathrm{pH}$ of wastewater to the entry and exit of the system planted and not planted 
BOD meter (WTW-OxiTop), the DCO, nitrites, nitrates and orthophosphate were determined by colorimetry to the assistance of a colorimeter (Hach DR/890).

\section{RESULTS AND DISCUSSIONS}

\section{Characteristics of the effluent to treat}

The waters to treat are of urban wastewater from the city of El-Oued, they are collected at the entrance of the sewage plant in Kouinine. The characteristics of this effluent are shown in Table 1.

All parameters measured for the raw wastewater fall in the range of the Values generally observed for the Urban Waste Water, with the exception of the value of nitrates which come without doubt of the oxidation of ammoniums to nitrite and then to nitrate.

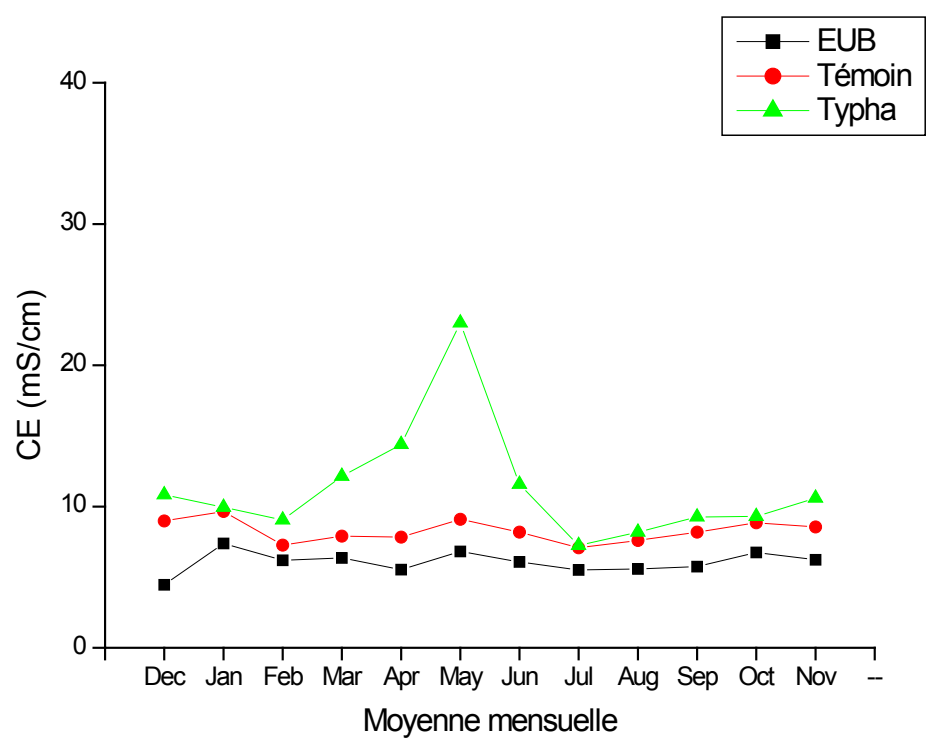

Fig. 3: Time evolution of the conductivity of the wastewater to the entry and exit of the system planted and not planted

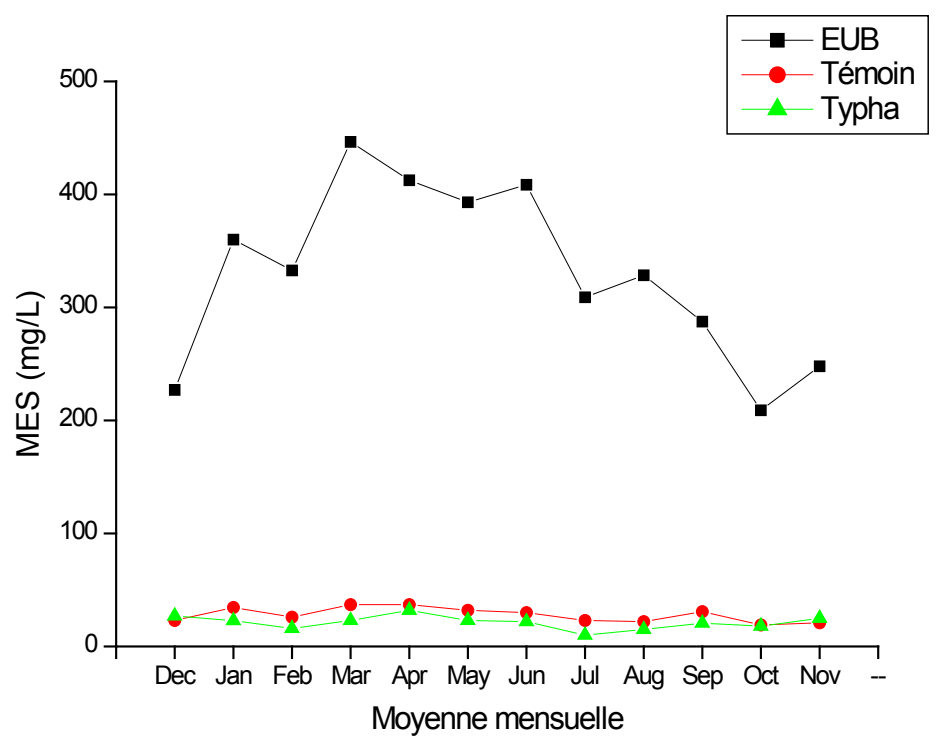

Fig. 4: Time evolution of SS of wastewater to the entry and exit of the system planted and not planted 


\section{Evolution of the $\mathrm{pH}$}

The evolution of the $\mathrm{pH}$ values of wastewater to the entry and exit of the system planted and not planted during the period from December 2013 to November 2014, are gathered in the figure 2.

Throughout the year of study for the bed planted where not planted, there is a slight acidification of purified water. The acidification for the bed planted is more important. This slight acidification of the environment can be interpreted by an oxidation of the $\mathrm{DCO}$ and $\mathrm{NH}_{4}{ }^{+}$, the carbon dioxide $\left(\mathrm{CO}_{2}\right)$ product of, the oxidation of the DCO acidifies the middle, nitrification (oxidation of $\mathrm{NH}_{4}^{+}$) causes a acidification of the filtrates ; plants can also release of root exudates (acids tannic and gallic), which cause acidification of the environment.

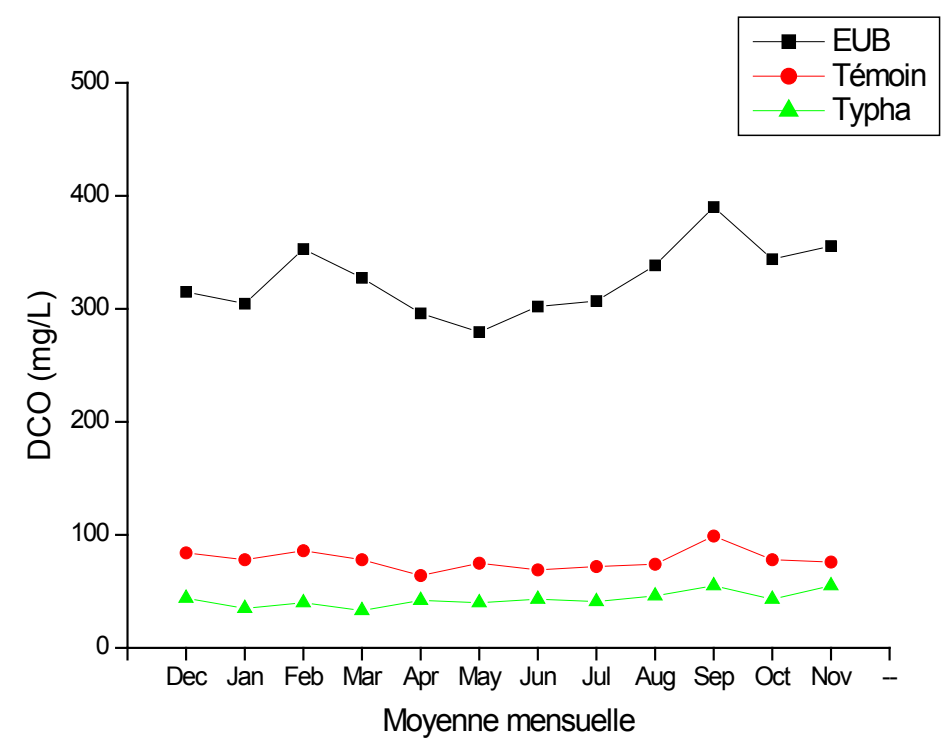

Fig. 5: Time evolution of the DCO of wastewater to the entry and exit of the system planted and not planted

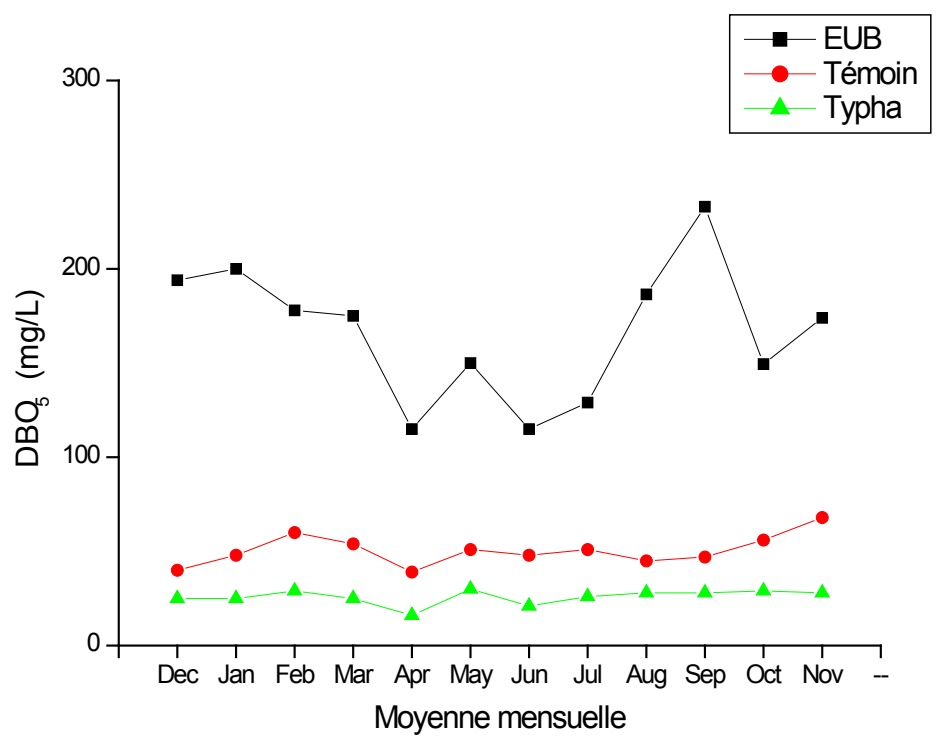

Fig. 6: Time evolution of the $\mathrm{BOD}_{5}$ of wastewater to the entry and exit of the system planted and not planted 


\section{The evolution of the EC}

The evolution of the values of the conductivity of the wastewater to the entry and exit of the system planted and not planted, during the period from December 2013 to November 2014, are gathered in the figure 3.

The conductivity increases to the output of the witness and the bed planted, this increase could be linked to the mineralization of organic matter. Our results are similar to those found by Finlayson and Chick $^{22}$, for the same plant and that interpret this phenomenon by evapotranspiration from the vegetation which tends to concentrate more of the effluent.

\section{Evolution of SS}

The evolution of the values of my of

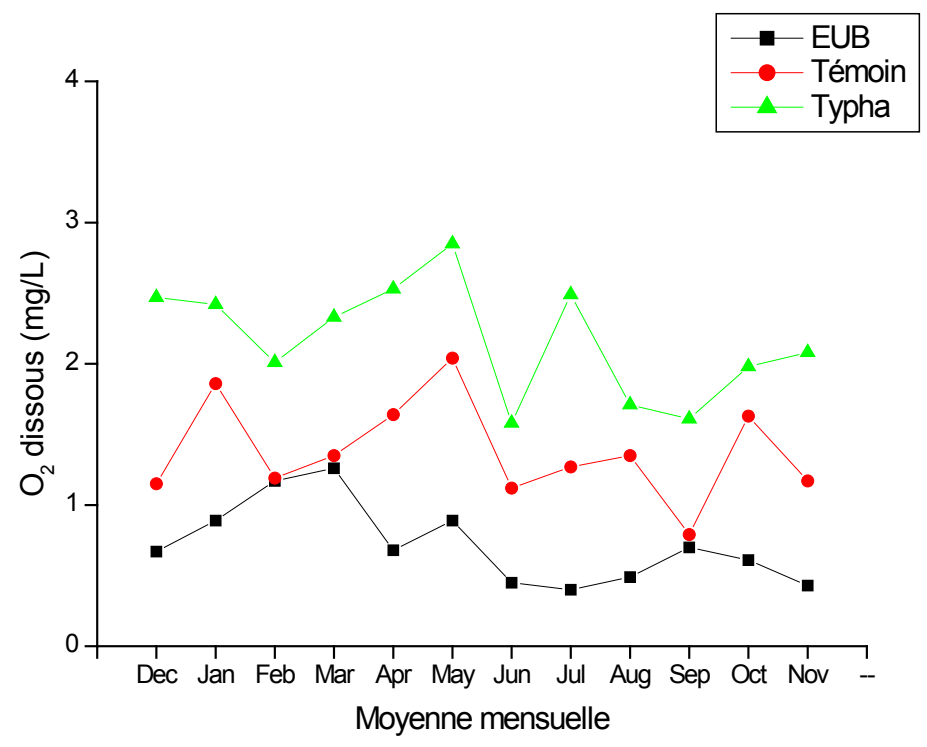

Fig. 7: Temporal Evolution of the dissolved oxygen of wastewater to the entry and exit of the system planted and not planted

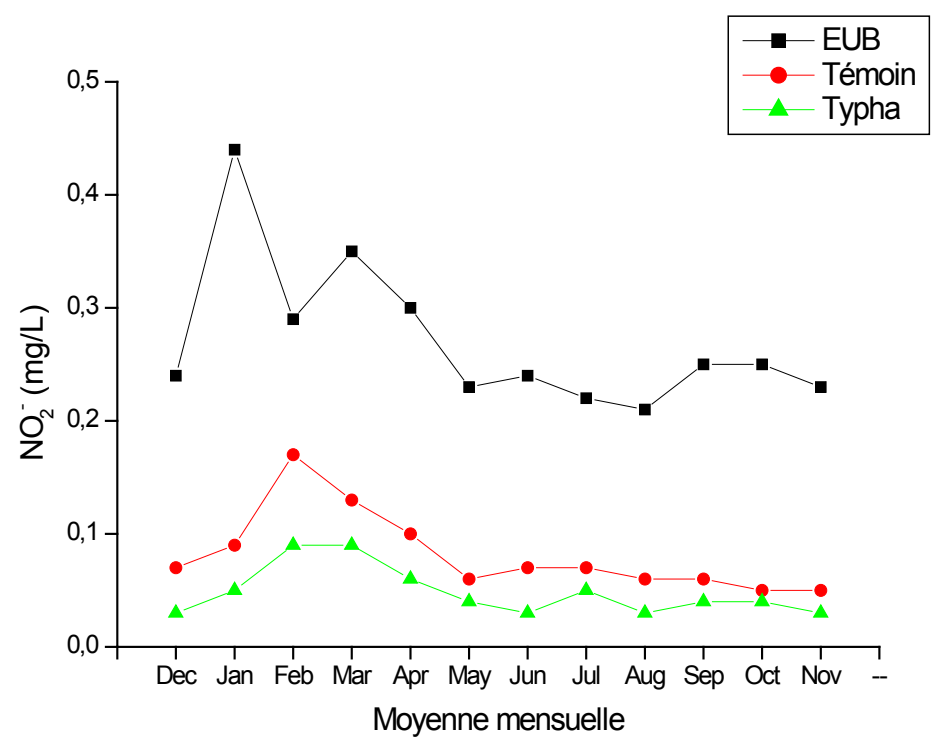

Fig. 8: Time evolution of nitrites for wastewater to the entry and exit of the system planted and not planted 
wastewater to the entry and exit of the system planted and not planted during the study period, are gathered in the figure 4.

One obtains yields of abatements of contents in suspension very satisfactory that in all cases exceed the $85 \%$. For the witness, the yields oscillate between the $89,29 \%$ (month of September) and $93,30 \%$ (month of August). The minimum yield for the bed planted is $88,11 \%$ (month of December) and this performance achieved $96,76 \%$ during the month of July. There is a small improvement in the retention of material in suspension when going from the bed not planted in bed planted because the most important part of contents in suspension is retained by filtration through the gravel, the roots of plants

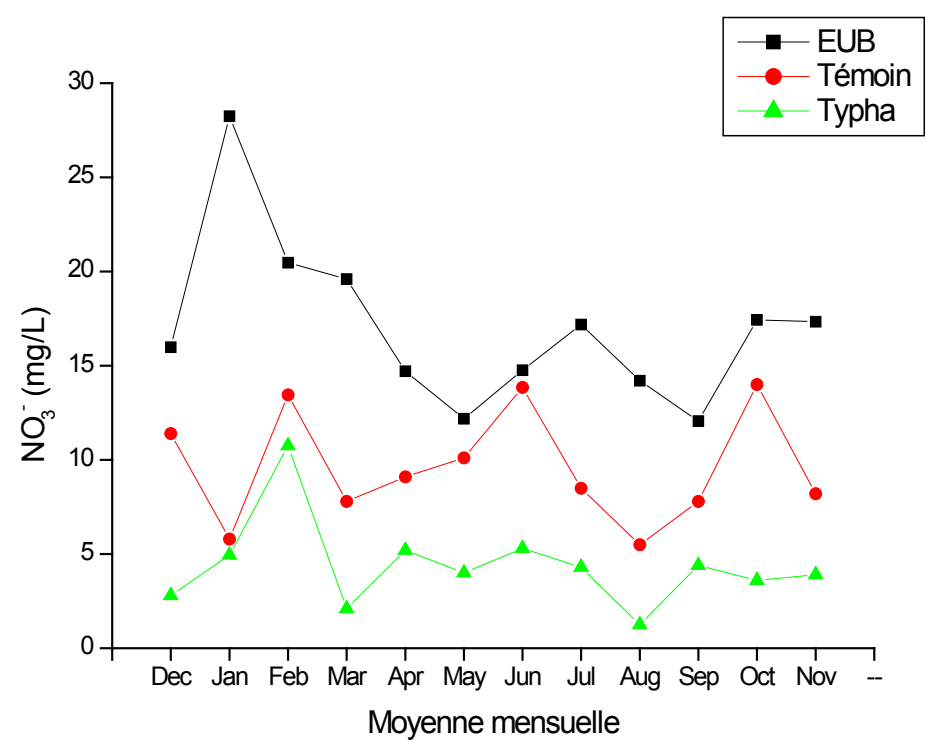

Fig. 9: Time evolution of nitrate for the wastewater to the entry and exit of the system planted and not planted

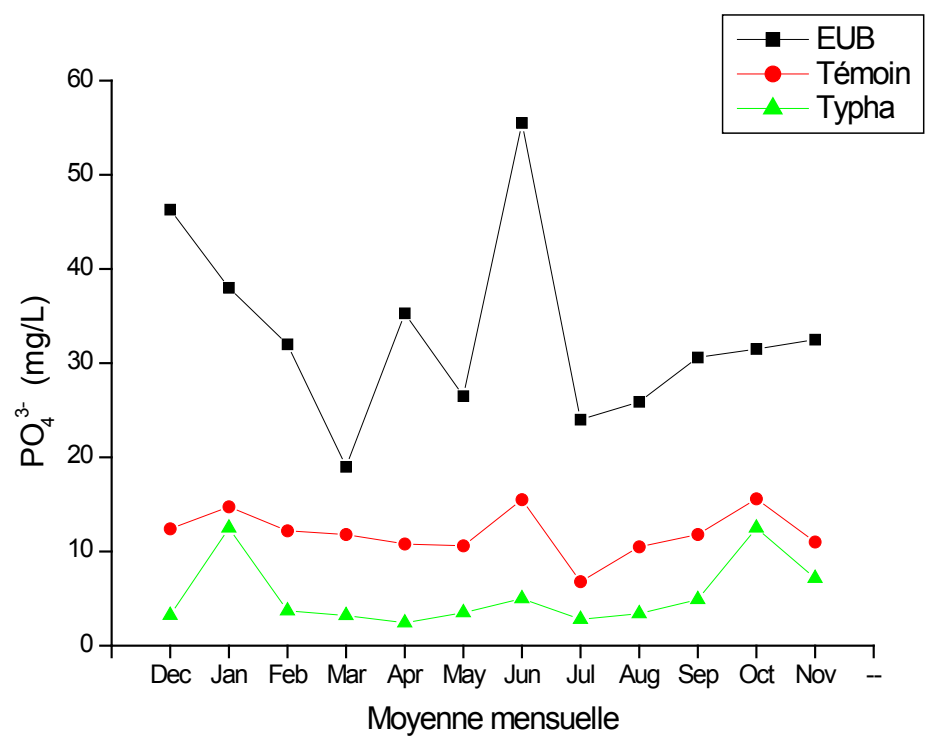

Fig. 10: Time evolution of orthophosphate for wastewater to the entry and exit of the system planted and not planted 
contribute to the retention of another part of contents in suspension.

\section{Evolution of the DCO}

The evolution of the values of the DCO of wastewater to the entry and exit of the system planted and not planted during the study period, are gathered in the figure 5 .

For the witness, the yields in terms of DCO oscillate between the 73,13 (month of May) and 78,63 (Month November), the minimum yield for the bed planted is $84.54 \%$ (month of November) and this performance reached 89.92 per cent during the month of March. A net improvement of the abatement of the DCO is observed when going from the witness to bed planted. The biological degradation by action of bacteria added to physical phenomena, filtration are without doubt to the origin of the drawdown of the organic matter. The plants are creating of physico-chemical conditions favorable to the oxidation of organic matter by the microbial flora. These bring oxygen in the massif filtering via the roots and rhizomes, something which allows the aerobic bacteria to proliferate is to ensure an oxidation of organic matter ${ }^{1}$.

The sedimentation of My and their filtration by the gravel and the roots of the plants have certainly contributed to the elimination of the carbonaceous pollutants.

\section{Evolution of the $\mathrm{BOD}_{5}$}

The evolution of the values of the $\mathrm{BOD}_{5}$ of wastewater to the entry and exit of the system planted and not planted during the study period, are gathered in the figure 6 .

For the witness, the yields in terms of $\mathrm{BOD}_{5}$ oscillate between $58,28 \%$ (month of June) and $79.83 \%$ (Month September). The minimum yield for the bed planted by the plant Typha is $79,84 \% \%$ (July) and this performance reached $87.98 \%$ during the month of September. The same phenomena of the abatement of the DCO are involved in the retention of the $\mathrm{BOD}_{5}$.

\section{Evolution of the dissolved oxygen}

The evolution of the values of the dissolved oxygen of wastewater to the entry and exit of the system planted and not planted during the study period, are gathered in the figure 7 .

A significant improvement in the quantity of dissolved oxygen is observed in the bed planted and in the bed not planted, for the maximum values going from $1.26 \mathrm{mg} / \mathrm{L}$ to $2.04 \mathrm{mg} / \mathrm{L}$ for the witness, 2.85 for the bed planted. The degradation of the organic matter fact that the waters become less loaded and therefore the oxygen concentration becomes more important.

\section{Evolution of nitrite}

The evolution of the values of nitrite of wastewater to the entry and exit of the systems planted and not planted, during the study period are gathered in the figure 8 .

For the witness, the yields of nitrites oscillate between $41,96 \%$ (month of February) and $80.64 \%$ (Month January). The minimum yield for the bed planted is $69.23 \%$ (month of February) and this performance achieved $88,84 \%$ during the month of January. The elimination of nitrite is significant enough in the beds planted and in the bed not planted, with a yield of $80.64 \%$ for the witness to a performance of $88,84 \%$ for the bed planted. Nitrites are oxidized to nitrates (nitration) by bacteria Nitrobacter and a party is assimilated by plants:

\section{Evolution of nitrate}

The evolution of the values of nitrate of wastewater to the entry and exit of the systems planted and not planted during the study period, are gathered in the figure 9 .

For the witness, the yields of nitrates oscillate between the $6.13 \%$ (month of June) and $79,47 \%$ (month of January). The minimum yield for the bed planted is $47,48 \%$ (month of February) and this performance reached $91.20 \%$ during the month of August. The elimination of nitrates is significant enough in the bed planted and in the bed not planted, a performance of $79,47 \%$ for the witness, one goes to $91,20 \%$ for the Typha. Nitrates are absorbed by the plants in the presence of light for photosynthesis

\section{Evolution of orthophosphate}

The evolution of the values of orthophosphate of wastewater to the entry and exit of the systems 
planted and not planted during the study period, are gathered in the figure 10 .

For the witness, the yields of orthophosphate oscillate between the 37.89 (month of March) and 73.22 (month of December). The minimum yield for the bed planted is $60,32 \%$ (month of October) and this performance reached $93.12 \%$ during the month of April. The assimilation can be done in different ways either by bacterial assimilation and/or, an assimilation by the plant: the plant assimilates for these fabrics in growth, the phosphorus through its rhizome and these roots or by adsorption by the massif filter. Our results are superior to those found by Abissy $^{9}$ who obtains a yield of $10 \%$.

\section{CONCLUSION}

This study, which covered the period from December 2013 to November 2014 with the follow-up of nine parameters. $\mathrm{pH}$, electrical conductivity, SS, COD, BOD5, dissolved oxygen, nitrite, nitrate and orthophosphate has allowed to show that the plant Typha which supports the conditions of very difficult climate, may very well be used for the purification of urban wastewater in an arid climate. Yields very satisfactory were obtained: for the particulate pollution and organic, the rates of drawdown have reached the $96,76 \%$ for the substances in suspension (SS), the $89,92 \%$ for the Chemical Oxygen Demand (COD), and $87,98 \%$ for the biochemical oxygen demand in 5 days (BOD5) with a net increase of the dissolved oxygen concentration. The elimination of nitrogen pollution and of phosphorus is translated by rates of drawdowns of $88,84 \%$ for nitrites, $91,20 \%$ for nitrates and $93,12 \%$ for the orthophosphate. The yields of purification for the different pollutants are very significant especially for particulate pollution and the organic pollution.

\section{REFERENCES}

1. Brix ,H. Use of constructed wetlands in water pollution control: historical development, present status, and future prospects, Wat. Sci. Tech 1994, 30(8), 209-223.

2. Tredwell, R. Effective approaches for environmental \& Wastewater Management and Training - The birdwood downs case studies in the Kimberley region of West Australia, Murdoch etc Conference.

3. Koné, D. purification of wastewater by lagooning with microphytes and macrophytes in West Africa and the Center: state of places, épuratoires performance.

4. Maïga ,A.;H. Performance épuratoires a chain of three basins in series of surface impoundment to microphytes under Sahelian climate: the case of the wastewater treatment plant of 21E (EIERETSHER group), Review. Water. Sci 2008, 21(4),399-411

5. Fonkou ,T. Macrophyte diversity in polluted and non-polluted wetlands in Cameroon, Env. Biology. 2005, 1(1),26-33.

6. Bianchi, V. Ecological engineering. 2011, 37,779-785.

7. Dong, H. J. approximately. Monit, 2012, 14, 1906-1913.

8. Al-Omari. A.; Fayyad .Mr. Treatment of domestic wastewater by subsurface flow constructed wetlands in Jordan. Desalination. 2003, 155:27-39

9. Abissy, Mr.; Mandi L. Use of rooted plants for the treatment of urban wastewater: The Case of reed. Rev. Sci. Water.1999, 12(2), 285-315.

10. Mandi, L,. Tests of wastewater treatment of MARRAKECH by water hyacinth. Rev. Water .Sci .1992, 5,313-333

11. Tiglyène. Removal of the Chrome by vertical infiltration of Phragmites australis (Cav.) Steudel. Rev. Sci. Water. 2005, 18 (2),171198.

12. Seidl, Mr. The system "lens of water Tilapia" an ecological solution promising for the treatment of wastewater in West Africa. Gallery of the water, Gallery of the water 2005, 3:11-17.

13. Ouattara, J.M.P. Treatment of urban wastewater by artificial marshes to Vertical drainage planted with Panicum maximum sub tropical climate, Euro.J Sci. Res 2008, 23(1), 25-40.

14. Nelson, M.Wetland systems for bioregenerative reclamation of Wastewater: from closed systems to developing countries. Life .Sup. biosph Sci. 1998, 5(3),357-369.

15. Nelson, M. Living off the land: resource 
efficiency of wetland wastewater treatment. Adv. Space Res. 2001, 27(9),1547-1556

16. Haberl, R. Constructed wetlands in Europe. Wat. Sci. Tech. 1995, 32(3), 305-315.

17. Kouakou, J. Development of a wet area planted simulated with Amaranthacea and Capri: Aridacea for the treatment of domestic wastewater, Report of African Technology Policy Studies Network (ATPS).

18. Nelson, M. New Paradigms: "Wastewater Gardens", creating urban oases and greenbelts by productive use of the nutrients and water in domestic sewage, conference on cities as Sustainable Ecosystems.2002

19. Achak, Mr. Rev. Sci. Water. 2011, 24(1):3551.

21. Cristina , S.C. Water Research.2007, 41:1790-1798.

20. Benredjel, F.; Ghoualem, H. Contribution to the physico-chemical characterization of rainwater in the region of Tizi-Ouzou. Treatment by the filters planted. Larhyss Journal. 2015, 23, 41-52

22. Finlayson, C.M.; Chick, A.J. Testing the potential of aquatic plants to treat slaughterhouse effluent, Waters Res. 1983, 17(4):415-422.

23. Finlayson. Treatment of Piggery effluent by Aquatic Plant Filter. biological wastes. 1987, 19, 179-196

24. Grismer, M.; Shepherd ,H. L. Seedlings in constructed wetlands help to treat agricultural processing wastewater. California Agriculture. 2011, 65(2), 73-79.

25. Tsala, N.G. Effect of $\mathrm{Fe}^{2+}, \mathrm{Mn}^{2+}$, $\mathrm{Zn}^{2+}$, and $\mathrm{Pb}^{2+}$ is $\mathrm{H}^{+} / \mathrm{K}$ + fluxes in excised Pistia stratiotes roots. Biologia Plantarum. 1994, 36(4),591-597.

26. Tanner, C.C. Organic matter accumulation during maturation of gravel-bed constructed wetlands treating FARM dairy wastewaters. Wat. Res. 1998, 32(10), 3046-3054

27. Nelson, M. Bioregenerative recycling of wastewater in Biosphere 2 using a constructed wetland: 2-year results. Ecological engi. 1999, 13, 189-197.

28. Taylor, C.R. Ecological engi. 2011, 37, 703710.

29. Seghairi, N. Possibilities of elimination of phosphates and nitrogen from domestic wastewater by using a filter planted of papyrus, the 4 International Congress Water, Waste \& Environment (EDE4) Agadir, Morocco, December 2012, 18-20.

30. Seghairi, N. Elimination of the copper present in industrial wastewater on a filter planted Tamarix. Mail of knowledge 2013, 15, 53-57

31. Nelson, M. Worldwide applications of Wastewater Gardens and Ecoscaping: decentralised systems, which transform sewage from Problem to Productive, Sustainable Resource. Conference on Decentralised Water and Wastewater Systems, Environmental Technology.2006

32. Hafouda, L. Agronomic follow-up of the pilot unit of sewage treatment by wet area artificial. Old Ksar of Témacine, Report of the National Institute of Agronomic Research of Algeria (INRAA). 2010

34. Badri, A. Contribution to the study bioremediation of ammonium and nitrate by imprata cylindrica. International seminar on the water resource in the Sahara.2011

35. Benslimane, Mr. Performance épuratoires and interest of the process of phytotraitement of wastewater by macrophytes plants. Mail of knowledge. 2013, 17, 47-51

36. Bensmina-Mimèche, L. Capacity of filters planted of macrophytes for the treatment of wastewater in the semi-arid climate, Mail of knowledge. 2013, 17,33-37.

37. Brix, H. Treatment of wastewater in the rhizosphere of wetland plants-The root-zone method. War. Sci. Tech. 1987, 19, 107-118.

38. Brix, H. Soil oxygenation in constructed reed beds: the role of macrophyte and soilatmosphere interface transport oxygen. 1990

39. Mimèche, L. Study of the feasibility of the installation of a sewage treatment plant of urban discharges by the filters planted in arid environment -application to the region of Biskra, Thesis of Doctorate in Sciences presented at the University of Biskra, 2014

40. Bensmina, L. Analysis of the purifying powers of a filter introduced Phragmite australis for the treatment of wastewater Sous-Climat Semi-Aride (region of Biskra). Inter .J. Envir Conf. Manag. 2010, 1(1), 10-15. 